\title{
Efficiency of Inorganic and Organic Nitrogen Fertilization on Cauliflower (Brassica oleraceae var. botrytis, L.) Curds Quality
}

\author{
Abdel-Razzak, H. S. ${ }^{1}$, T. H. Gamel ${ }^{2}$ and A. B. El-Nasharty ${ }^{3}$
}

\begin{abstract}
Two experiments were established at the Experimental Station Farm, Faculty of Agriculture, Alexandria University in two winter seasons of 2006/2007 and $2007 / 2008$ to evaluate the effects of application three levels of inorganic $\mathrm{N}$ fertilizer $\left(40,80\right.$ and $120 \mathrm{~kg} \mathrm{~N}$ fad. ${ }^{-1}$ as ammonium nitrate) and control treatment (without addition, soil $\mathrm{N})$, three rates of chicken manure $(5,10$ and $15 \mathrm{~m}^{3}$ fad. $^{-1}$ ) in addition to control treatment (without application chicken manure) as well as their interactions effect on curd quality of cauliflower "Amshiry" cultivar.

The results showed positive effects of using either inorganic or organic $\mathbf{N}$ fertilizers on cauliflower curds quality characters. The inorganic $\mathbf{N}$ form was more effective in the presence than in absence of organic fertilizer concerning curds quality. The application of high level of inorganic $N$ fertilizer $\left(120 \mathrm{~kg} N\right.$ fad. $\left.^{-1}\right)$, significantly, increased curd weight, phenolic compounds, concentrations of $\mathrm{Ca}$ and $\mathrm{Mg}$ of curds, and significantly decreased inflorescence stalks length of cauliflower curds. However, both medium and high levels of inorganic $N$ form (80 and $120 \mathrm{~kg} \mathrm{~N}$ fad. $^{-1}$ ) augmented curd diameter, dry matter content, protein nitrogen, true protein, non protein nitrogen as well as concentrations of some macro and micro-nutrient (N, P, K, Na and $\mathrm{Zn}$ ) of curds compared with other treatments. Chicken manure at the highest rate $\left(15 \mathrm{~m}^{3}\right.$ fad. $\left.^{-1}\right)$ reflected clear superior in all curds quality characters under consideration. Positive changes in all studied parameters viz. curd quality characteristics and nutritional value were obtained in response to the collaborative effect of both inorganic and organic $\mathbf{N}$ fertilization. The results of the current study indicated that combination of inorganic $N$ level $(80 \mathrm{~kg} \mathrm{~N}$ fad. ${ }^{-1}$ as $\left.\mathrm{NH}_{4} \mathrm{NO}_{3}\right)$ with chicken manure rate $\left(15 \mathrm{~m}^{3}\right.$ fad. $^{-1}$; i.e., $72 \mathrm{~kg} \mathrm{~N}$ fad. $^{-1}$ ) gave the superior curd quality characteristics with high nutritional values for cauliflower "Amshiry" cultivar under the study region conditions.
\end{abstract}

Key words: Cauliflower, chicken manure, curd quality, $\mathbf{N}$ fertilizer, nitrate content, phenolic compounds.

\section{INTRODUCTION}

Vegetable crops produced by using organic manures are gaining increasing popularity and importance because of the public perception that they may be of higher quality, less chemical residues and

\footnotetext{
${ }^{1}$ Vegetable Crops Dept., Fac. Agriculture, Alexandria Univ., Egypt

${ }^{2}$ Food Science \& Technology Dept., Fac. Agriculture,

Alexandria Univ., Egypt

${ }^{3}$ Fertilization Technology Dept., National Research Centre,

Dokki, Cairo, Egypt

Received December21, 2008, Accepted December 30, 2008
}

increases of health concern (Rani and Mallareddy, 2007).

In Egypt, there are several governmental initiatives to reduce the use of chemical fertilizers and compensate that by using organic fertilizers (Hasanin, 2007). Several researches are advocating the integrated nutrient management with organic and inorganic fertilizers to conserve the soil health as well as to obtain good quality product (Rani and Mallareddy, 2007). The importance of using organic fertilizer and decrease using inorganic fertilizer in plant production is one of the most important ways in health protection (Badawy et al., 2007).

Cauliflower (Brassica oleraceae var. botrytis, L.) is the second most important inflorescence vegetables after globe artichoke and before broccoli in many places of the world. It is an inexpensive winter crop and can be consumed as a fresh or frozen vegetable. In Egypt, cauliflower's curds are consumed cooked, fried, boiled and pickled. It is well known that, cauliflower have enormous nutritional and medicinal values due to its high contents of vitamins; i.e., C, K, B5 and B6, dietary fibers, folic acid, and minerals such as $\mathrm{K}, \mathrm{Mg}, \mathrm{P}, \mathrm{Zn}$ and Fe (Nonnecke, 1989).

Concerning of health aspect has been raised the attention towards phytochemicals from different plant sources. Among phytochemicals, phenolic compounds may exert a protective role against various diseases, and can prevent the formation of cancer causing agents due to their antibacterial and antioxidant properties (Ramarathnam et al., 1997, Silva et al., 2004, and Sousa et al., 2008). Cauliflower represents one of the vegetables that contain polyphenolic compounds with good antioxidant activity (Ramarathnam et al., 1997).

Proper use of organic manures and inorganic N fertilizers is very essential not only for obtaining high yield and great quality but also to maintain soil health and sustainability for longer period (Rani and Mallareddy, 2007). Nitrogen is the most difficult element to manage in a fertilization system in order to ensure an adequate, but not excessive, amount of available $\mathrm{N}$ within the rhizosphere from planting to harvest (Sorensen et al., 1995) as high doses of $\mathrm{N}$ may 
cause excessive accumulation of nitrates or non protein nitrogen in different plant parts of some vegetables including cauliflower (Pimpini et al., 1973; Greenwood and Hunt, 1986; Lisiewska and Kmiecik, 1996 and Elia et al., 1998).

Little information is available on the integrated use of organic and inorganic $\mathrm{N}$ fertilization on cauliflower curds quality, macro- and micro-nutrient concentrations as well as nutritional value including phenolic compounds and nitrate content. Therefore, the current investigation was undertaken to evaluate the effect of applied inorganic $\mathrm{N}\left(\mathrm{NH}_{4} \mathrm{NO}_{3}\right)$ and organic $\mathrm{N}$ (chicken manure) fertilizers on curds quality characteristics. Also, to find out the best combination level of both inorganic and organic $\mathrm{N}$ forms used on nutritional value and chemical constituents of "Amshiry" cultivar cauliflower curds.

\section{MATERIALS AND METHODS}

Curds quality characters of cauliflower plants "Amshiry" cultivar were studied using two field experiments conducted at the Agricultural Experimental Station Farm, Faculty of Agriculture, Alexandria University through two successive growing winter seasons of 2006/2007 and 2007/2008.

Representative soil samples were collected from 0$30 \mathrm{~cm}$ soil depth, at random, to represent the experimental field after soil preparation and before adding chicken manure in both seasons. Samples of chicken manure used were also taken for analysis. The samples were air dried, crushed by wooden hammer, sieved through $2 \mathrm{~mm}$ sieve, thoroughly mixed and used to determine several physical and chemical characters. The $\mathrm{pH}$ and electric conductivity (E.C.) were determined in soil/water extract (1:2.5 w:v) and chicken manure/water extract $(1: 10 \mathrm{w}: \mathrm{v})$. Calcium carbonate $\left(\mathrm{CaCO}_{3}\right)$ content of the soil was determined using Calcimeter method. Potassium dichromate method was used to determine organic matter (O.M.) content. Total nitrogen $(\mathrm{N})$ was determined using Bauschi digestion and distillation apparatus. Available phosphorus (P) content of soil was extracted using sodium bicarbonate method. Available potassium $(\mathrm{K})$ and magnesium $(\mathrm{Mg})$ were extracted using ammonium acetate. The amounts of available $\mathrm{Fe}, \mathrm{Mn}, \mathrm{Zn}$ and $\mathrm{Cu}$ were extracted using DTPA method. All the previous methods were carried out according to Chapman and Pratt (1978) procedures.

Some physical and chemical characteristics of both soil and chicken manure samples are shown in Tables 1 and 2 , respectively.

\section{Organic fertilizer source and rates:}

Chicken manure used was obtained from the Experimental Poultry Station, (Abies region), Faculty of Agriculture, Alexandria University. The quantity of chicken manure used is divided into three rates; 05, 10 and $15 \mathrm{~m}^{3}$ fad. $^{-1}$ in addition to control treatment (without chicken manure addition). These three rates represent 24,48 and $72 \mathrm{~kg} \mathrm{~N}$ fad. $^{-1}$. The organic manure rates were incorporated and mixed thoroughly with the surface soil layer $(0-20 \mathrm{~cm})$ one week before transplanting (Table 3).

\section{Inorganic $\mathbf{N}$ fertilizer source and levels:}

Ammonium nitrate $\left(\mathrm{NH}_{4} \mathrm{NO}_{3}, 33.5 \% \mathrm{~N}\right)$ was used as inorganic $\mathrm{N}$ fertilizer based on the results of previous study obtained by Abdel-Razzak et al., (2008) which concluded that ammonium nitrate fertilizer gave the best curds quality of the same cauliflower cultivar "Amshiry" comparing with other commercial inorganic $\mathrm{N}$ fertilizers as ammonium sulphate and urea. Inorganic $\mathrm{N}$ levels were planned to be $0,40,80$ and $120 \mathrm{~kg} \mathrm{~N}$ fad..$^{-1}$. These $\mathrm{N}$ levels were performed by combining three equal divided side dressings and added at approximately 3-4 weeks intervals. The actual inorganic $\mathrm{N}$ levels used and the dates of $\mathrm{N}$ fertilization application are shown in Table (3). All levels of $\mathrm{N}$ fertilizer were applied to the soil surface by hand immediately after labor weed control and followed by irrigation. Phosphorus and potassium fertilizers were broadcast-applied to the all experimental plots at $100 \mathrm{~kg} \mathrm{fad} .^{-1}$ as calcium supper phosphate $\left(15.5 \% \mathrm{P}_{2} \mathrm{O}_{5}\right)$ and potassium sulphate $(48.0 \%$ $\mathrm{K}_{2} \mathrm{O}$ ). Phosphate fertilizer was applied as a basal dose during soil preparation; whereas, potassium fertilizer was applied twice, half was applied as a basal dose and the other half quantity was added one month after planting.

Table 1. Some physical and chemical soil properties of the experimental sites during 2006/2007and 2007/2008 seasons

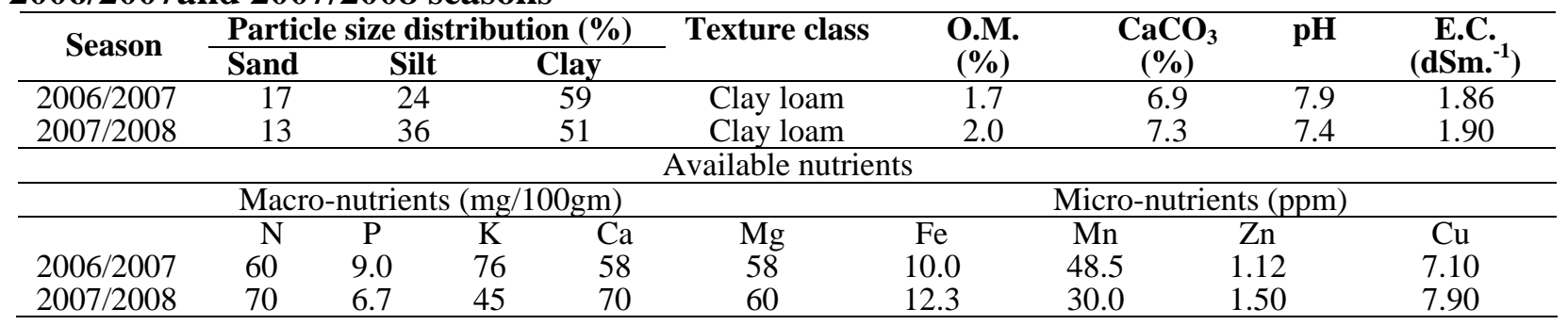


Table 2. Some physical and chemical characteristics of chicken manure used during 2006/2007 and 2007/2008 seasons

\begin{tabular}{|c|c|c|}
\hline & & \\
\hline Characteristics & $2006 / 2007$ & $2007 / 2008$ \\
\hline Moisture content (\%) & 47 & 45 \\
\hline Weight $1 \mathrm{~m}^{3}$ of manure $(\mathrm{Kg})$ & 374 & 400 \\
\hline Organic matter $(\%)$ & 33.9 & 31.5 \\
\hline Organic Carbon (\%) & 19.7 & 18.3 \\
\hline Nitrogen $(\%)$ & 1.3 & 1.2 \\
\hline $\mathrm{C} / \mathrm{N}$ ratio & $15: 1$ & $15: 1$ \\
\hline${ }^{\mathrm{x}} \mathrm{pH}$ & 7.6 & 8.0 \\
\hline Total dissolved salts (\%) & 0.47 & 0.38 \\
\hline & Macro-nutrients (\%) & \\
\hline${ }^{\mathrm{y}} \mathrm{P}$ & 0.12 & 0.17 \\
\hline $\mathrm{K}$ & 1.80 & 1.50 \\
\hline $\mathrm{Ca}$ & 0.44 & 0.80 \\
\hline $\mathrm{Mg}$ & 0.14 & 0.17 \\
\hline & Micro-nutrients (ppm) & \\
\hline $\mathrm{Fe}$ & 60.70 & 40.90 \\
\hline $\mathrm{Mn}$ & 6.10 & 9.00 \\
\hline $\mathrm{Zn}$ & 18.50 & 20.00 \\
\hline $\mathrm{Cu}$ & 36.50 & 30.50 \\
\hline
\end{tabular}

$(1: 10 \mathrm{w}: \mathrm{v})$ chicken manure : water extract.

${ }^{y}$ Total P content determined based on chicken manure digestion (Isamu, 1972).

Table 3. Dates of chicken manure application, transplanting, levels of mineral $\mathrm{N}$ application, first and last harvest of "Amshiry" cv. cauliflower in two winter seasons of 2006/2007 and 2007/2008

\begin{tabular}{|c|c|c|c|c|c|c|c|c|c|}
\hline \multirow{2}{*}{$\begin{array}{l}\text { Planting } \\
\text { seasons }\end{array}$} & \multirow{2}{*}{\multicolumn{2}{|c|}{$\begin{array}{c}\text { Date and rate } \\
\text { of chicken } \\
\text { manure } \\
\text { fad. } .^{-1}\end{array}$}} & \multirow[t]{2}{*}{$\begin{array}{c}\text { Transplanting } \\
\text { date }\end{array}$} & \multirow{2}{*}{$\begin{array}{c}\text { Levels of } \\
\text { mineral N } \\
\mathrm{NH}_{4} \mathrm{NO}_{3} \\
\left(\mathrm{~kg} \mathrm{~N} \mathrm{fad.}^{-1}\right) \\
\end{array}$} & \multicolumn{3}{|c|}{$\begin{array}{c}\text { Dates of mineral N } \\
\text { applications }\end{array}$} & \multirow[t]{2}{*}{$\begin{array}{c}\text { First } \\
\text { harvest }\end{array}$} & \multirow[t]{2}{*}{$\begin{array}{c}\text { Last } \\
\text { harvest }\end{array}$} \\
\hline & & & & & First & Second & Third & & \\
\hline \multirow{6}{*}{$\begin{array}{l}2006 / \\
2007\end{array}$} & \multicolumn{2}{|c|}{17 Nov. } & \multirow{6}{*}{$\begin{array}{c}22 \\
\text { Nov. }\end{array}$} & \multirow{2}{*}{\multicolumn{2}{|c|}{$\begin{array}{c}10 \\
\text { Dec. }\end{array}$}} & \multirow{2}{*}{$\begin{array}{l}11 \\
\text { Jan. }\end{array}$} & \multirow{2}{*}{$\begin{array}{c}2 \\
\text { Feb. }\end{array}$} & \multirow{6}{*}{$\begin{array}{c}26 \\
\text { Feb. }\end{array}$} & \multirow{6}{*}{$\begin{array}{l}29 \\
\text { Mar. }\end{array}$} \\
\hline & $\left(\mathrm{m}^{3}\right)$ & $(\operatorname{kg~N})$ & & & & & & & \\
\hline & 00 & 00.00 & & 00 & 00 & 00 & 00 & & \\
\hline & 05 & 24.31 & & 40 & 13.33 & 13.33 & 13.33 & & \\
\hline & 10 & 48.62 & & 80 & 26.67 & 26.67 & 26.67 & & \\
\hline & 15 & 72.93 & & 120 & 40.00 & 40.00 & 40.00 & & \\
\hline \multirow{6}{*}{$\begin{array}{l}2007 / \\
2008\end{array}$} & \multicolumn{2}{|c|}{20 Nov. } & & & 19 & 18 & 10 & \multirow{6}{*}{$\begin{array}{c}5 \\
\text { Mar. }\end{array}$} & \multirow{6}{*}{$\begin{array}{c}3 \\
\text { Apr. }\end{array}$} \\
\hline & $\left(\mathrm{m}^{3}\right)$ & $(\operatorname{kg~N})$ & & & Dec. & Jan. & Feb. & & \\
\hline & 00 & 00.00 & 26 & 00 & 00 & 00 & 00 & & \\
\hline & 05 & 24.00 & Nov. & 40 & 13.33 & 13.33 & 13.33 & & \\
\hline & 10 & 48.00 & & 80 & 26.67 & 26.67 & 26.67 & & \\
\hline & 15 & 72.00 & & 120 & 40.00 & 40.00 & 40.00 & & \\
\hline
\end{tabular}

Healthy cauliflower seedlings of "Amshiry" cultivar (three- to four-leaves stage) were transplanted on one side of the ridge at a distance of $50 \mathrm{~cm}$ on November $22^{\text {nd }}$ and $26^{\text {th }}$ in 2006 and 2007 seasons, respectively (Table 3 ).

The normal cultural practices used for the cauliflower production, i.e. irrigation, weed and pest control were accomplished according to the common cultivation in cauliflower field production.

\section{Experimental design}

Three replications of field experiment were carried out in a split-plot system with a randomized complete blocks design (R.C.B.D.). Each replicate consisted of
16 treatments representing all combinations among the four levels of inorganic $\mathrm{N}$ fertilizer $(0,40,80$ and 120 $\mathrm{Kg} \mathrm{N}$ fad. $^{-1}$, NH4NO3) and four rates of organic fertilizer $\left(0,5,10\right.$ and $15 \mathrm{~m}^{3} \mathrm{fad}^{-1}$, chicken manure).

The main plots were assigned to the levels of inorganic $\mathrm{N}$ fertilizer, while chicken manure rates occupied as sub-plot treatments and they were placed randomly in each main plot. Each sub-plot consisted of four rows $4.0 \mathrm{~m}$ length and $0.7 \mathrm{~m}$ width and the plot area was $12 \mathrm{~m}^{2}$. A guard row was left without planting to separate each two adjacent sub-plots. 


\section{Data recorded:}

Cauliflower curd is a mass of abortive florets attached to thick, hypertrophied branches at the top of a short thick stem; as a peculiar inflorescence consisting of thick, fleshy, strongly ramified flower stalk; as edible malformed and condensed flowers and flower stems (Nonnecke, 1989).

During plants maturity period (90-130 days after transplanting), five randomly selected cauliflower plants of each plot were cut at ground level at harvestable size, then separated into wrapper leaves, rest of leaves, curds and stems. The five curds were graded to determine the following characters:

(a) Curd weight (g); cauliflower curds were cut, trimmed to marketable form, and used to determine the average weight of five net curds.

(b) Curd diameter $(\mathrm{cm})$; it was measured across the widest part of the curd.

(c) Inflorescence stalks length $(\mathrm{cm})$; it was measured from three different sides from starting of branch up to the top of the curd.

(d) Curds dry matter (\%); the content of curd's dry matter was determined according to the Association of Official Analytical Chemists (AOAC, 1995) by drying $5 \pm 0.5 \mathrm{~g}$ curd samples at $110^{\circ} \mathrm{C}$ in a drying oven until a constant weight.

Nutritional value of cauliflower curds:

(a) Protein nitrogen and non protein nitrogen of cauliflower curds were determined using the micro-Kjeldahl method (AOAC, 1995). The non protein nitrogen was determined after precipitation of protein by using Trichloro acetic acid $30 \%$.

(b) The true proteins contents were calculated using a conversion factor (6.25) as following; the true protein $=$ protein $\mathrm{N} \times 6.25$.

(c) Nitrate content of curds was determined using magnesium oxide-Devarda Alloy stem distillation method (Cottenei et al., 1982).

(d) Polyphenol compounds of curds as tannic acid were determined according to the colorimetric method proposed by Gutfinger, (1981). Five g of fresh curds was extracted with $100 \mathrm{ml}$ of (methanol/water solution 3/1). After filtration into 100-ml volumetric flask, the total volume of extract was complete to mark. One $\mathrm{ml}$ from the final extract was transferred into a $25 \mathrm{ml}$ volumetric flask and a Folin-Ciocalteau reagent $(0.5 \mathrm{ml})$ was added. Three min later $1.0 \mathrm{ml}$ of a saturated sodium carbonate solution was added and the flask was filled up to volume with distilled water and stored in the dark for one hour. A blue color formation indicated the presence of phenols. The absorbance of the solution was measured at $725 \mathrm{~nm}$ by spectrophotometer against blank.

(e) Determination of macro-nutrients; N, P, K, Ca and $\mathrm{Mg}$ and micro-nutrients; $\mathrm{Na}, \mathrm{Fe}, \mathrm{Mn}, \mathrm{Zn}$, and $\mathrm{Cu}$ concentrations (Chapman and Pratt, 1978).

\section{Cauliflower curds sample preparation for minerals} analysis:

Small portions of cauliflower curds were washed carefully by diluted HCL $(0.001 \mathrm{~N})$, followed by a tap water and finally two successive distilled water. The crud pieces were dried at $70^{\circ} \mathrm{C}$ for constant weight, and grounded in stainless steel mill to pass through $0.5 \mathrm{~mm}$ sieve. Based on Jones et al., (1991) method, the curd sample $(1.0 \mathrm{~g})$ was subjected to ashing in a muffle furnace at $500^{\circ} \mathrm{C}$ for $6 \mathrm{hrs}$. After cooling in disscator, ash was dissolved by adding $5 \mathrm{ml}$ concentrated mineral acids mixture (3:1 $\mathrm{HCl}: \mathrm{HNO}_{3}$ conc.), transferred quantitatively into $100 \mathrm{ml}$ volumetric flask and completed to mark with de-ionized water. The ash solution was homogenized and filtered through ashless filter paper in a polythene container with sealed cover and kept refrigerated for the minerals analysis.

Nitrogen $(\mathrm{N})$ concentration; was determined using the micro-Kjeldahl method (AOAC, 1995). Phosphorus (P)concentration; was estimated using Spectrophotometer (Zaies).

Potassium (K), Sodium (Na) and Calcium (Ca) concentrations; were determined, using Flame photometer (Jenway, PFP7).

Concentrations of $\mathrm{Mg}, \mathrm{Fe}, \mathrm{Mn}, \mathrm{Zn}$, and $\mathrm{Cu}$ were determined by using Atomic Absorption Spectrophotometer (GBC 932 AA).

\section{Statistical Analysis:}

The obtained data were subjected to statistical analysis using the analysis of variance procedure as outlined by Co-Stat Software computer program for statistics (2004). Means for the two factors under consideration and their interactions were compared according to Duncan's multiple range test at a probability error of 5\% level (Steel and Torrie, 1980).

\section{Curd growth characteristics}

\section{(A) Effect of inorganic nitrogen fertilizer levels:}

Table (4) showed that either curd weight or curd diameter was, significantly, increased by increasing the inorganic $\mathrm{N}$ levels in both seasons. In this direction, the highest level of inorganic $\mathrm{N}$ fertilizer; $120 \mathrm{~kg} \mathrm{~N}$ fad. $^{-1}$ was more effective for increasing curds weight and diameter progressively than those of other lower treatments levels. Addition of $120 \mathrm{~kg} \mathrm{~N}$ fad. $^{-1}$ increased 
both curd weight and diameter by $7.96 \%, 11.47 \%$ and $9.06 \%, 13.18 \%$ in the first and second seasons, in succession compared with control treatment (zero level; soil N). These results are in the same line of the recent findings of Abdel-Razzak et al., (2008) who reported that both curd weight and diameter of cauliflower, significantly, increased linearly with increasing levels of applied mineral $\mathrm{N}$ fertilizer up to $120 \mathrm{~kg} \mathrm{~N}$ fad. ${ }^{-1}$. Also, Bjelic (1996) and Thompson et al., (2000) reported that curd weight and diameter, were generally responsive to mineral $\mathrm{N}$ application compared with control treatment. On the other hand, the medium and high $\mathrm{N}$ levels (80 and $120 \mathrm{~kg} \mathrm{~N} \mathrm{fad} .^{-1}$ ), significantly, decreased inflorescence stalks length than control treatment in both seasons. That might be related to a limiting $\mathrm{N}$ supply (40 kg N fad. ${ }^{-1}$ or zero $\mathrm{N}$, soil $\mathrm{N}$ ) is associated with curd looseness. Such looseness of the curd can be regarded as the onset of bolting. Then the peduncles start to separate and elongate with the lowest level of inorganic $\mathrm{N}$ fertilization (Rather et al., 1999). A significant increase was observed in the curds dry matter content as a result of application of any level of inorganic $\mathrm{N}$ fertilizer comparing with control treatment, in both seasons. A similar trend was obtained by Rather et al., (1999) and Farrag et al., (2000), who found that increasing mineral $\mathrm{N}$ rates, significantly, increased dry matter content of cauliflower curds. This could be explained by the fact that $\mathrm{N}$ is one of the most important constituents of all proteins and nucleic acids and hence of all protoplasm and chlorophyll. This would supply the more rapidly the synthesized carbohydrates that necessary for more dry matter accumulation in plant organs (Russel, 1973).

\section{(B) Effect of organic nitrogen fertilizer (chicken manure) rates:}

Table (4) showed significant linear increment of chicken manure rates up to $15 \mathrm{~m}^{3} \mathrm{fad}^{-1}$ in curds weight, diameter and dry matter content during both seasons of experiments. The highest organic $\mathrm{N}$ rate; $15 \mathrm{~m}^{3}$ fad. $^{-1}$ recorded maximum curd weight $(1.827,1.879 \mathrm{~kg})$, curd diameter $(38.06,33.92 \mathrm{~cm})$ and curd dry matter content $(10.34,10.29 \%)$ in both seasons, respectively. These values are corresponding for $(28.12 \%, 34.32 \%)$, $(33.59 \%, 22.68 \%)$ and $(14.63 \%, 12.83 \%)$ increases in curds weight, diameter, and dry matter content compared with control treatment (without chicken manure addition; soil organic matter) in the first and second seasons, in succession. The enhancement effect of chicken manure application could be related to the fact that, chicken manure is considered as a rich source of $\mathrm{N}$ and providing slow release of nutrients during the growth season (Hasanin, 2007). Therefore, it creates better nutrients absorption and favors the growth and development of good root system which in turn reflects better vegetative growth, photosynthetic activity and dry matter accumulation (Abou El-Magd et al., 2006). On the other hand, the same organic $\mathrm{N}$ rate; $15 \mathrm{~m}^{3} \mathrm{fad}^{-1}$ recorded the minimum inflorescence stalks length $(10.74,9.31 \mathrm{~cm})$ than other chicken manure rates in the first and second seasons, respectively. This result may attributed to the fact that chicken manure can offer quantity of $\mathrm{N}$ for soil micro-organisms activation, which are effective in nutrients availability through convert the nutrients from unavailable to available form for growing plants (El-Leboudi et al., 1984 and Solieman et al., 2006), which in turn, can give vigorous growth of cauliflower plants accordingly, decrease curds looseness.

\section{(C) Effect of interaction (inorganic $\mathrm{N}$ levels $\mathrm{x}$ organic $\mathrm{N}$ rates):}

Cauliflower curds characteristics were, significantly, improved by the collaborative addition of both inorganic $\mathrm{N}$ fertilizer and organic manure (Table 4). The highest values of curd weight (1.942 and 2.000 $\mathrm{kg}$ ) and curd diameter (39.42 and $34.83 \mathrm{~cm}$ ) were obtained by using the highest level of inorganic N (120 $\mathrm{kg} \mathrm{N} \mathrm{fad.}^{-1}$ ) and the highest rate of chicken manure (15 $\mathrm{m}^{3} \mathrm{fad}^{-1}$ ) treatment followed by application the medium level of inorganic $\mathrm{N}\left(80 \mathrm{~kg} \mathrm{~N}\right.$ fad. $\left.^{-1}\right)$ and the highest rate of chicken manure $\left(15 \mathrm{~m}^{3} \mathrm{fad}^{-1}\right)$ in both seasons, respectively. However, the later treatment $(80 \mathrm{~kg} \mathrm{~N}$ fad.' $\left.{ }^{1}\right)$ and the highest rate of chicken manure $\left(15 \mathrm{~m}^{3} \mathrm{fad}^{-1}\right)$ increased the percentage of curd dry matter $(10.75 \%$ and $10.65 \%$ ) followed by interaction treatment of the highest levels of inorganic $\mathrm{N}\left(120 \mathrm{~kg} \mathrm{~N}\right.$ fad. $\left.{ }^{-1}\right)$ and the highest rate of chicken manure $\left(15 \mathrm{~m}^{3} \mathrm{fad}^{-1}\right)$, particularly, in the first season. But, the differences between both later treatments were not high enough to be significant in the second one. These results may show the positive effect of inorganic $\mathrm{N}$ source used viz. ammonium nitrate which could increase decomposition rate of organic matter i.e., chicken manure and thereby release more nutrients in available form for growing cauliflower plants. On the other side, the lowest values of inflorescence stalks length $(9.24,8.92 \mathrm{~cm})$ were recorded by using the highest level of inorganic $\mathrm{N}\left(120 \mathrm{~kg} \mathrm{~N}\right.$ fad. $\left.{ }^{-1}\right)$ and the highest rate of organic $\mathrm{N}\left(15 \mathrm{~m}^{3} \mathrm{fad}^{-1}\right)$ in both seasons. The relatively short cauliflower inflorescence stalks length with higher applications of both inorganic and organic $\mathrm{N}$ fertilization could be explained perhaps by the curd tissue being softer at a high $\mathrm{N}$ availability, thereby having less physical resistance to inflorescence stalk elongation. Therefore, the inflorescence stalks increased in thickness and tended to become short and thick, which in turn can increase from curds quality; i.e., compactness. This finding is in agreement with Nonnecke, (1989), who clarified that the flower stem with branchlets of 



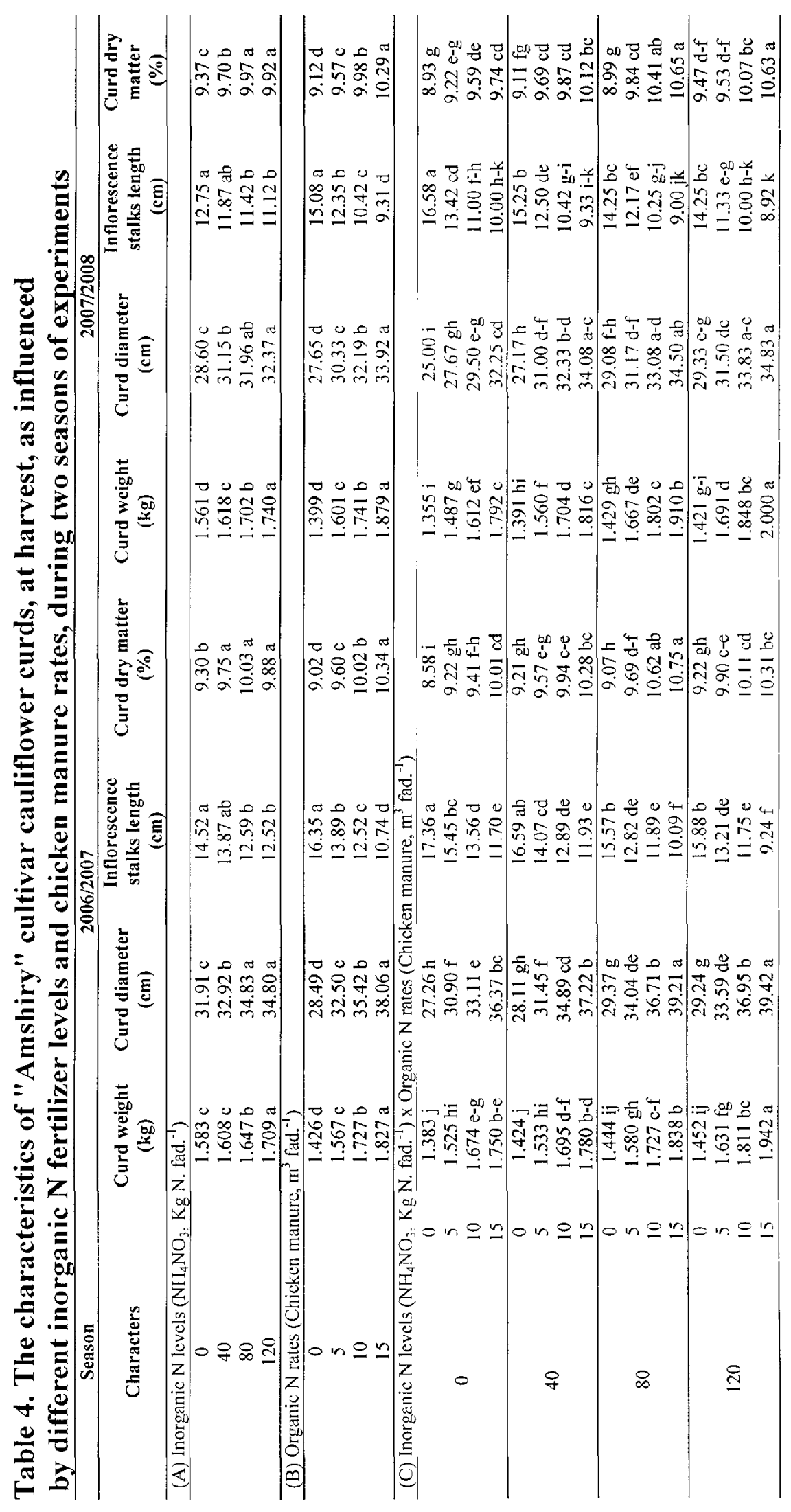


cauliflower becoming thicker as they shorten to form a regular corymbs.

\section{Nutritional value of cauliflower curds:}

\section{(A) Effect of inorganic nitrogen fertilizer levels:}

Addition of inorganic $\mathrm{N}$ fertilizer improved the nutrient content of cauliflower curds (Table 5). All three levels of inorganic $\mathrm{N}$ had significant effect on the content of protein nitrogen and true protein in the first season compared with control treatment (soil N), while there were insignificant differences among these three levels. In the second one, significant differences were observed with the addition of 80 and $120 \mathrm{Kg} \mathrm{N}$ fad. $^{-1}$ compared with the lowest level of inorganic $\mathrm{N}(40 \mathrm{Kg}$ $\mathrm{N}$ fad. $^{-1}$ ) and control treatment (zero level, soil $\mathrm{N}$ ). Protein concentration in plants is highly dependent on $\mathrm{N}$ availability. The non-protein nitrogen increased significantly parallel with inorganic $\mathrm{N}$ fertilizer rate up to $80 \mathrm{Kg} \mathrm{N}$ fad. $^{-1}$ in both seasons. The levels of nitrate; the main constitute of non-protein nitrogen; and phenolic compounds increased significantly in correspond to the inorganic $\mathrm{N}$ levels as elevated from zero to $120 \mathrm{Kg} \mathrm{N} \mathrm{fad.}{ }^{-1}$. With an increase in the inorganic $\mathrm{N}$ fertilization levels from 40 to $120 \mathrm{Kg} \mathrm{N}$ fad. $^{-1}$, the content of nitrate rose by $31.58 \%$ and $37.04 \%$ in the first and second seasons, respectively. The same result was indicated by Lisiewska and Kmiecik (1996), who reported that the content of nitrates in cauliflower increased by $33.0 \%$ by increasing $\mathrm{N}$ fertilization dose from 80 to $120 \mathrm{~kg} \mathrm{~N} \mathrm{ha}^{-1}$, confirming the role of inorganic $\mathrm{N}$ fertilization in the accumulation of nitrate (Greenwood and Hunt, 1986). Generally, nitrate accumulation in vegetables could be due to the imbalance between nitrate absorption and reduction by plants. When nitrate-N is adequate in soil, plants usually absorb much more nitrate than they can reduce. Therefore, reducing soil nitrate and nitrate absorption by plants are of great importance for the purpose of reducing nitrate accumulation in vegetables (Wang and $\mathrm{Li}, 2003)$. It is expected to get high content of nitrate in cauliflower curds as a result of using inorganic $\mathrm{N}$ levels compared with organic $\mathrm{N}$ rates in both seasons. The same result was obtained by Montemurro et al., (2008), who illustrated in lettuce plants that mineral fertilizer treatments showed the highest values of nitrate in both leafstalks and leaves than those reached by organic treatments.

Dietary polyphenols represent a group of secondary metabolites which widely occur mainly in fruits, vegetables, and cereals. These are mostly derivatives, and/or isomers of flavones, isoflavones, flavonols, catechins, and phenolic acids (Duthie et al., 2000). Our results indicated that addition of different levels of inorganic $\mathrm{N}$ fertilizer caused gradual increase in phenolic acids content of curds from 2.75 and 2.78 up to 3.15 and $3.13 \mathrm{mg} / \mathrm{DM}$ in the first and second seasons, respectively.

\section{(B) Effect of organic nitrogen fertilizer (chicken manure) rates:}

The organic $\mathrm{N}$ fertilizer exhibited similar effect to the inorganic one (Table 5), as the rate of organic $\mathrm{N}$ fertilizer increased the protein and non protein nitrogen, true protein, nitrate content and phenolic compounds are increased in both seasons. The medium and high rates of chicken manure (10 and $15 \mathrm{~m}^{3}$ fad. $^{-1}$ ) have comparable effect on protein nitrogen and true protein levels in the first season and nitrate level in both seasons. Phenolic compounds which are the main antioxidants in vegetables are increased significantly by 14.85 and $15.75 \%$ in corresponding to the addition of the highest rate of chicken manure $\left(15 \mathrm{~m}^{3} \mathrm{fad}^{-1}\right)$ in both seasons of experiment. The rate of nitrate accumulation was low in reflect to the addition of organic $\mathrm{N}$ compared to the effect of inorganic N. Inorganic $\mathrm{N}$ fertilizer found to accumulate more nitrate in the curds. Wang et al., (2008) reported that $\mathrm{N}$ sources containing $\mathrm{NO}_{3}$ and/or $\mathrm{NH}_{4}-\mathrm{N}$ are widely used in vegetables production in different countries.

The $\mathrm{N}$ fertilizer added to the soil is the major source of nitrate accumulation, and nitrate- $\mathrm{N}$ fertilizers tend to increase nitrate concentration in vegetable crops much more than other fertilizers. This confirms the results of Pimpini et al., (1973), who argued that the accumulation of nitrate in cauliflower plants could be influenced to a great extend by an application of mineral fertilizers containing nitrate as ammonium nitrate or calcium nitrate compared with cyanamide, ammonium sulphate or urea.

\section{(C) Effect of interaction (inorganic $\mathrm{N}$ levels $\mathrm{x}$ organic $\mathrm{N}$ rates):}

Table (5) showed that the doses of both types of $\mathrm{N}$ fertilization increased all the nutrients content increased in parallel. Addition of 120 and $80 \mathrm{Kg} \mathrm{N} \mathrm{fad.}{ }^{-1}$ of ammonium nitrate in coordination with 15 and $10 \mathrm{~m}^{3}$ $\mathrm{fad}^{-1}$ of chicken manure in corresponding order, exhibited the highest effect among all other interaction treatments. The true protein increased from 17.98 to $24.56 \%$ in the first season and from 17.85 to $25.56 \%$ in the second season as a result of addition of $120 \mathrm{Kg} \mathrm{N}$ fad. $^{-1}$ inorganic and $15 \mathrm{~m}^{3}$ fad. $^{-1}$ of organic $\mathrm{N}$ fertilizers. That reflects an increase of $36.6 \%$ and $43.2 \%$ of the true protein in the first and second seasons, respectively. Similar trend was observed by Everaarts and Booij, (2000) for white cabbage plants where high $\mathrm{N}$ fertilization up to $400 \mathrm{~kg} \mathrm{~N} \mathrm{ha}^{-1}$ was associated with high protein content of the leaves. 


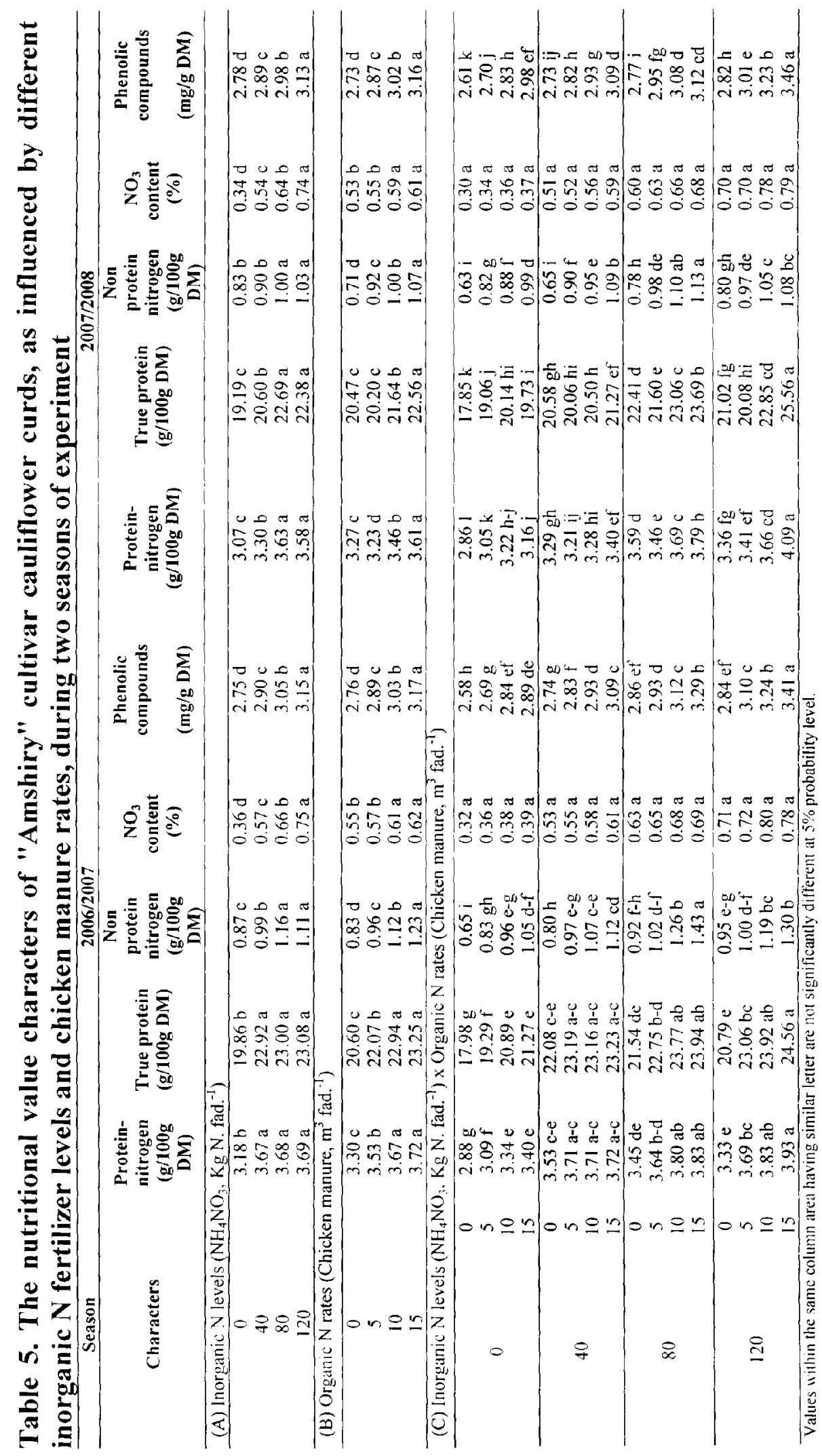


Nitrate content as a harmful ion in cauliflower curds considers as an important characteristic to be monitored in cauliflower, particularly, for children and patients nutrition (Makovic and Djurovka, 1990). Results presented in Table (5) showed that all interaction treatments were insignificantly affected nitrate content of cauliflower curds. These results were in the same tendency of Makovic and Djurovka, (1990), who found that during cauliflower fertilization with increasing $\mathrm{N}$ doses from 0 to $200 \mathrm{~kg} \mathrm{~N}^{-1}$ nitrate content of curds was insignificantly changed. In general, nitrate accumulates in vegetables originated from residual soil $\mathrm{N}$, as well as from application of inorganic and organic $\mathrm{N}$ fertilization. For this reason, the key measure for reducing nitrate accumulation in vegetables lies in proper $\mathrm{N}$ fertilizer management (Schenk, 1998). Addition of high level of $\mathrm{N}$ was reported as the key factor associated with excessive accumulation of nitrates in different species of vegetables (Greenwood and Hunt, 1986 and Elia et al., 1998). Similar to previous obtained information by Pimpini et al., (1973), our results under line the important for the practice as the grower inclines to apply higher $\mathrm{N}$ doses to gain higher yields for vegetable crops. Moreover, a satisfactory high yield quantity should be ascertained, but on the other hand a jumpy increase of the nitrate in the plant should be avoided.

Polyphenols are the most abundant antioxidants in human diets. They are secondary metabolites of plants and denote many substances with aromatic rings (Duthie et al., 2000). Extra amount of phenolic compounds was developed by the addition of both inorganic and organic fertilizers. The highest levels of both inorganic $\mathrm{N}$ fertilizer and chicken manure raised the phenolic compounds in the curds by $32.2 \%$ and $32.5 \%$ in the first and second seasons, respectively. Increasing the level of phenolic compounds in cauliflower curds posses an advantage for health benefit where those phytochemicals exhibit many biologically significant functions, such as protection against oxidative stress, and degenerative diseases.

\section{Macro- and micro-nutrient concentrations of cauliflower curds:}

The results presented in Tables (6 and 7) demonstrate the average concentrations of macro- and micro-nutrient in curds of cauliflower "Amshiry" cultivar as affected by both inorganic and organic $\mathrm{N}$ fertilizers as well as their interactions.

\section{Macronutrient concentration}

\section{(A) Effect of inorganic nitrogen fertilizer levels:}

Table (6) showed that macro-nutrient (N, P, K, Ca, and $\mathrm{Mg}$ ) were, significantly, affected by adding inorganic $\mathrm{N}$ levels in both seasons. The medium and high levels of mineral $\mathrm{N}$ fertilizer (80 and $120 \mathrm{~kg} \mathrm{~N}$ fad. ${ }^{1}$ ) were more superior for increasing the contents of all macro-nutrient under consideration compared with the lowest level of inorganic $\mathrm{N}\left(40 \mathrm{~kg} \mathrm{~N} \mathrm{fad}{ }^{-1}\right)$ in both seasons, with the exception of $\mathrm{K}$ concentration which was insignificantly affected in the second one. This result is in accordance with Csizinszky (1996), who found that $\mathrm{N}$ and $\mathrm{P}$ concentrations in green cauliflower curds were higher with mineral $\mathrm{N}$ fertilizer at 294 than at $98 \mathrm{~kg} \mathrm{ha}^{-1}$. Superiority of the medium and high levels of inorganic $\mathrm{N}\left(\mathrm{NH}_{4} \mathrm{NO}_{3}\right)$ regarding $\mathrm{N}$ status in cauliflower curds compared with control treatment (soil $\mathrm{N}$ ) in both seasons could be a resultant of relatively lower availability rate of $\mathrm{NH}_{4}$ form and presence of $\mathrm{NO}_{3}$, which seemed to be relatively easier in absorption by plants as indicated by El-Leboudi et al., (1984). Generally, the positive influences of mineral $\mathrm{N}$ application on macro-nutrient contents of cauliflower curds appeared to enhance vegetative growth which ultimately leads to more photosynthetic activities (Sharma et al., 2002), accordingly increased assimilation of carbohydrates and their translocation to the reproductive tissues, namely curds.

\section{(B) Effect of organic nitrogen fertilizer (chicken manure) rates:}

The results in table (6) reflected significant differences in concentrations of macro-nutrient; i.e., $\mathrm{N}$, $\mathrm{P}, \mathrm{K}, \mathrm{Ca}$ and $\mathrm{Mg}$ of cauliflower curds in both seasons of experiment as a result of using various rates of chicken manure. It is noticeable that the highest rate of chicken manure $\left(15 \mathrm{~m}^{3} \mathrm{fad}^{-1}\right)$ was superior for increasing the percentage of all macro-nutrient concentrations in cauliflower curds linearly in both seasons of study. The superiority of chicken manure for $\mathrm{N}, \mathrm{P}, \mathrm{K}, \mathrm{Ca}$ and $\mathrm{Mg}$ contents can be attributed to its narrow $\mathrm{C} / \mathrm{N}$ ratio (Table 2) which lead to rapid mineralization and decomposition in soil (Helmy and Ramadan, 2008). Moreover, it can be referred to the ability of organic matter in rendering soil nutrients more available and chelating of these elements by humic substances. That will help in increasing the respiration rate, the metabolism and the growth of plants, causing the plant to require more nutrients from soil and fertilizers (El-Shafie and El-Gamaily, 2002). It is interested to find out that chicken manure at the highest rate $\left(15 \mathrm{~m}^{3} \mathrm{fad}^{-1}\right)$ relatively increased percentage of all macro-nutrient contents under consideration more than inorganic $\mathrm{N}$ fertilizer in both seasons. This finding is similar to that obtained in cabbage (Smith and Hadley, 1988 and Zahradnik and Petrikova, 2007). Zahradnik and Petrikova, (2007) found in head cabbage that $\mathrm{Mg}$ content was, significantly, higher when the organic fertilizers were used compared with mineral fertilizers. 


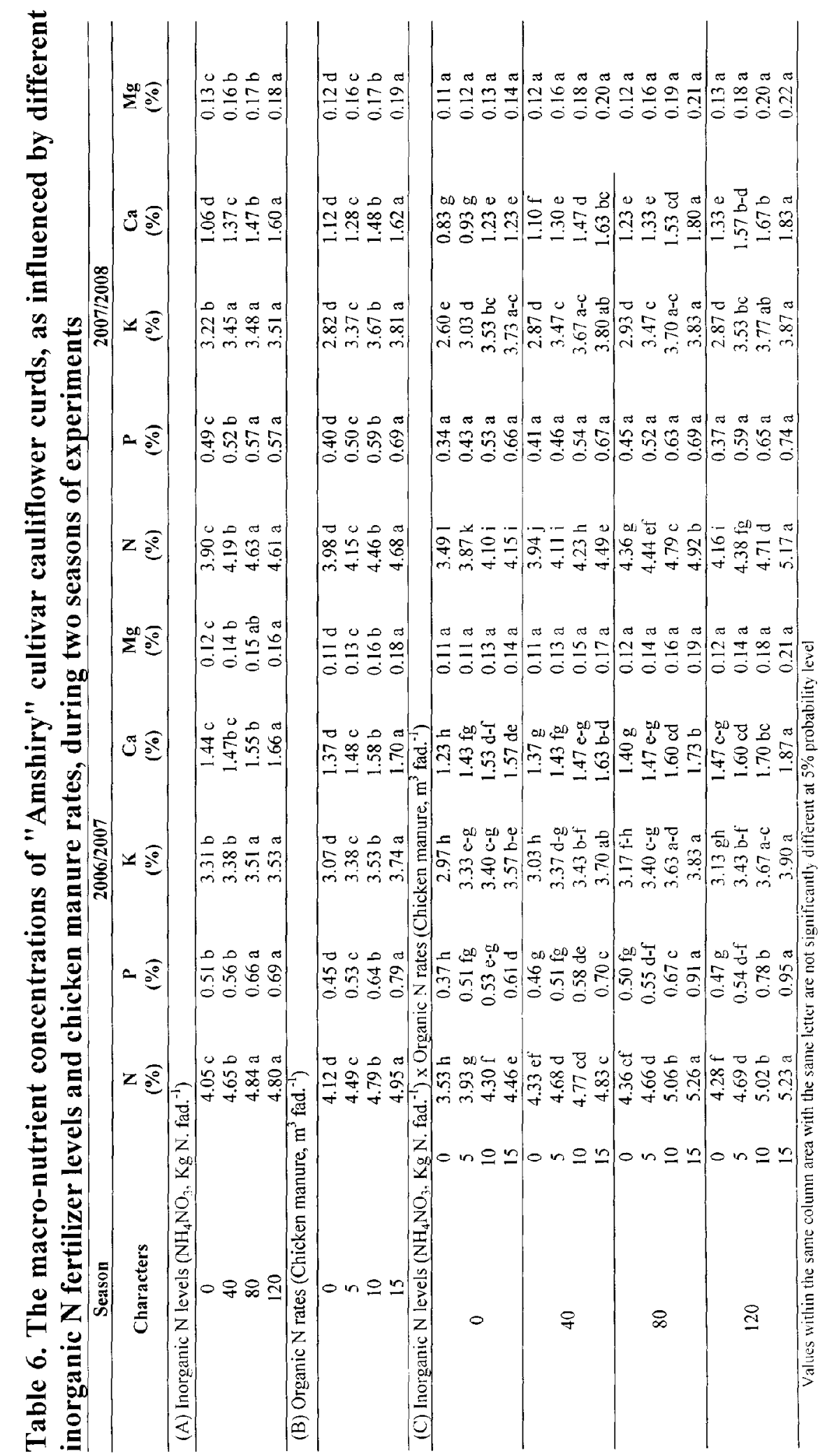


Magnesium is important for human health mainly for skin, bones and enzyme production. The previous result can support the finding of Smith and Hadley, (1988) that organic $\mathrm{N}$ is initially unavailable when applied to the soil. However, $\mathrm{N}$ is subsequently released at varying rates during growth of plants, depending on the nature of the proteins involved in, by microbial degradation in the soil. Therefore, it can be stated that $\mathrm{N}$ release characteristics of chicken manure applied seem better synchronized for the nutrient requirement of cauliflower crop than inorganic $\mathrm{N}$ form; i.e. ammonium nitrate.

\section{(C) Effect of interaction (inorganic $\mathrm{N}$ levels $\mathrm{x}$} organic $\mathrm{N}$ rates):

Table (6) revealed that the interaction treatments between the medium and high levels of inorganic $\mathrm{N}$ (80 and $120 \mathrm{~kg} \mathrm{~N} \mathrm{fad.} .^{-1}$ ) combine with the highest rate of chicken manure $\left(15 \mathrm{~m}^{3}\right.$ fad. $\left.^{-1}\right)$ had a significant effect on $\mathrm{N}, \mathrm{K}$ and $\mathrm{Ca}$ concentrations in both seasons and on $\mathrm{P}$ concentration in the first season only. However, concentrations of $\mathrm{Mg}$ in both seasons and $\mathrm{P}$ in the second one were insignificant indicates that both factors acted independently from each others. High percentages of $\mathrm{N}, \mathrm{P}, \mathrm{K}$ and $\mathrm{Ca}$ of cauliflower curds were recorded when plants received the highest combine levels of inorganic $\mathrm{N}$ (120 kg N fad. $\left.{ }^{-1}\right)$ and chicken manure (15 $\left.\mathrm{m}^{3} \mathrm{fad}^{-1}\right)$. That may be contributed to the ability of inorganic $\mathrm{N}$ to accelerate organic manure degradation. In fact, the rapid degradation of complex organic substances into less complex compounds, which are subsequently transformed in low molecular weight organic elements, allows more elements to be utilized by the plants (Montemurro et al., 2008).

\section{Micronutrient concentration}

\section{(A) Effect of inorganic nitrogen fertilizer levels:}

Micro-nutrient concentrations exhibited different behavior under various inorganic $\mathrm{N}$ fertilizer levels during the two cultivation seasons (Table 7). In the first one, $\mathrm{Mn}$ and $\mathrm{Zn}$ concentrations were affected by inorganic $\mathrm{N}$ fertilizer levels, while, $\mathrm{Na}, \mathrm{Fe}$, and $\mathrm{Cu}$ concentrations were insignificantly affected by any application. However in the second season, the results illustrated a progressive significant increase in curd's $\mathrm{Na}, \mathrm{Fe}, \mathrm{Zn}$, and $\mathrm{Cu}$ contents with the application of inorganic $\mathrm{N}$ fertilizer up to $120 \mathrm{~kg} \mathrm{~N}$ fad. $^{-1}$. Similar findings were obtained by Csizinszky (1996), who mentioned that $\mathrm{Fe}$ and $\mathrm{Zn}$ concentrations in green cauliflower curds increased with increasing inorganic $\mathrm{N}$ level up to $294 \mathrm{~kg} \mathrm{~N} \mathrm{ha}^{-1}$. On the contrary, gradual decrease in curd's Mn content occurred when $\mathrm{N}$ applied level reached to the highest level $\left(120 \mathrm{~kg} \mathrm{~N} \mathrm{fad}^{-1}\right)$ in both seasons. This result can be explained based on carbohydrates synthesis required Mn as coenzymes such as nicotine amide adenine dinucleotide (NAD) malic enzyme and phosphoenol pyruvate carboxykinase. These enzymes have an absolute $\mathrm{Mn}$ requirement that can not be replaced by $\mathrm{Mg}$. So, the more $\mathrm{N}$ added, the more carbohydrates synthesis, the more Mn required (Romheld and Marschner, 1991). This may illustrate the decreasing in $\mathrm{Mn}$ concentration with inorganic $\mathrm{N}$ increasing.

A positive response of inorganic $\mathrm{N}$ fertilizer applied levels on micro-nutrient contents during the second season could be refer to the available amount of most micro-nutrients present in the soil for growing plants was relatively high comparing with the first one (Table $1)$.

\section{(B) Effect of organic nitrogen fertilizer (chicken manure) rates:}

Results in Table (7) indicated that the content of all micro-nutrient in cauliflower curds was, significantly, increased with increasing chicken manure up to the highest rate; $15 \mathrm{~m}^{3}$ fad. $^{-1}$ in most cases. It is noticeable that the highest rate of chicken manure $\left(15 \mathrm{~m}^{3} \mathrm{fad}^{-1}\right)$ recorded the highest values of some micro-nutrient contents more than any level of inorganic $\mathrm{N}$ fertilizer. This was true in both growing seasons. This result coincide with the finding of Ahmed et al., (2008), who demonstrated that organic fertilization besides providing plants with a source of $\mathrm{N}$ undoubtedly supplied the growing plants with also the required micro- and macro-nutrient elements. Naturally, such elements play an important role in the metabolic processes of plants such as photosynthesis, respiration and carbohydrate synthesis (Marschner, 1994). Chicken manure contains macro- and micro-nutrients other than $\mathrm{N}$ (Table 2) which must have contributed to their superiority over the treatments that received the inorganic $\mathrm{N}$ levels. The favorable effect of chicken manure on the micro-nutrient content might be refer to that, chicken manure may have acted as chelating agents caused nutrients forms more readily absorbed by plants. In addition to, the production of organic and inorganic acids during the degradation of such organic manure as a result of the microorganism's activities must lead to decrease in soil $\mathrm{pH}$ which would produce more chelating ions, and consequently, increase in available forms of elements in the rhizosphere zone as reported by ElShafie and El-Gamaily, (2002); Helmy and Ramadan, (2008).

\section{(C) Effect of interaction (inorganic $\mathrm{N}$ levels $\mathrm{x}$ organic $\mathrm{N}$ rates):}

Table (7) revealed that the interaction between different inorganic $\mathrm{N}$ levels and chicken manure rates had a significant effect on micro-nutrient concentrations (Fe, $\mathrm{Mn}, \mathrm{Zn}$ and $\mathrm{Cu}$ ) but with different trends in both 
seasons of study. For example, the highest values of Fe

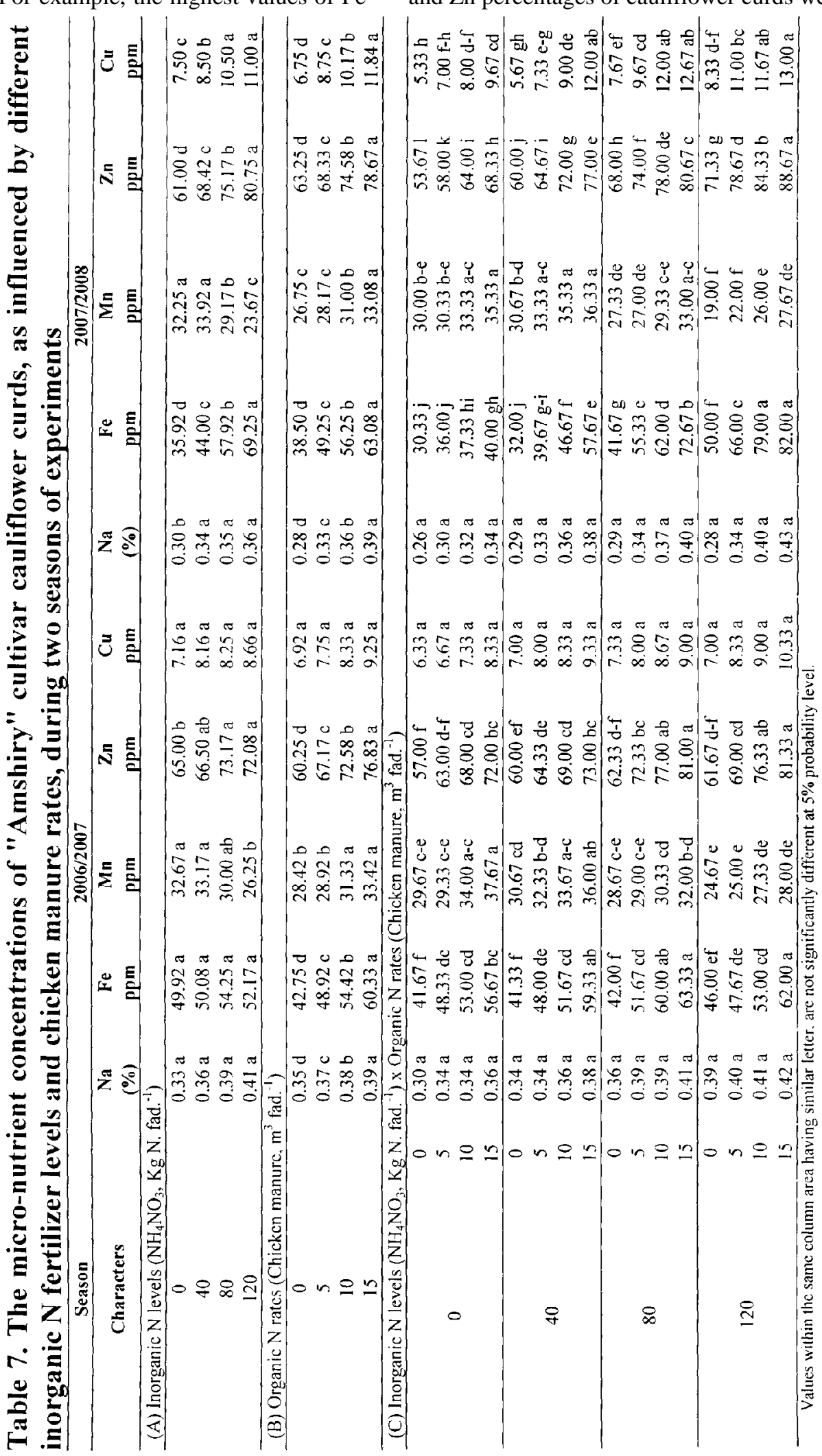


when plants fertilized with the medium or the highest level of inorganic $\mathrm{N}$ fertilizer (80 or $120 \mathrm{~kg} \mathrm{~N}$ fad. $^{-1}$ ) and the highest rate of organic $\mathrm{N}$ fertilizer $\left(15 \mathrm{~m}^{3} \mathrm{fad}^{-1}\right)$ in the first season. However, in the second one the highest values of $\mathrm{Fe}$ and $\mathrm{Zn}$ percentages were recorded when cauliflower plants fertilized with the highest level of inorganic $\mathrm{N}$ fertilizer $\left(120 \mathrm{~kg} \mathrm{~N} \mathrm{fad} .^{-1}\right)$ and the medium or the highest rate of chicken manure (10 or 15 $\mathrm{m}^{3}$ fad. $\left.^{-1}\right)$. With the exception of $\mathrm{Na}$ and $\mathrm{Cu}$ concentrations were insignificantly affected by any interaction treatment in both seasons or in the first one each in order.

It is obvious from the results of the current study that the interaction between the medium or the highest level of inorganic $\mathrm{N}$ (80 or $120 \mathrm{~kg} \mathrm{~N} \mathrm{fad}^{-1}$ ) and the highest rate of organic $\mathrm{N}\left(15 \mathrm{~m}^{3}\right.$ fad. $\left.^{-1}\right)$ showed significant superior effect on most macro- and micronutrient concentrations such as $\mathrm{N}, \mathrm{P}, \mathrm{K}, \mathrm{Ca}, \mathrm{Fe}, \mathrm{Zn}$ and $\mathrm{Cu}$. Such results could be refer to that $\mathrm{N}$ element has an active role in improving roots dimension by increasing division and elongation of cell, and in turn enhanced nutrient absorption. Moreover, large root surface allow an increase in the microorganisms as bacteria population activities resulted from degradation of organic matter, namely chicken manure (Kaoulnik et al., 1981).

\section{CONCLUSION}

Nitrogen fertilization, as an important agricultural practice for cauliflower crop production, has to be well managed in order to obtain maximum yield with high quality. Ammonium nitrate as inorganic $\mathrm{N}$ fertilizer and chicken manure as organic one can offer good production for cauliflower plants with better curds quality. Instead of increasing the amounts of inorganic $\mathrm{N}$ fertilizer in cauliflower fields, the collaborative effect of inorganic $\mathrm{N}$ fertilizer ( $80 \mathrm{~kg} \mathrm{~N}$ fad. ${ }^{-1}$ as $\mathrm{NH}_{4} \mathrm{NO}_{3}$ ) and organic $\mathrm{N}$ fertilizer $\left(15 \mathrm{~m}^{3}\right.$ fad. $^{-1}$; i.e., $72 \mathrm{~kg} \mathrm{~N}$ fad. $^{-1}$ as chicken manure) would be recommended as the best combination not only for obtaining good curds quality characters with high nutritional value of cauliflower "Amshiry" cultivar but also for reduction the amounts of inorganic $\mathrm{N}$ fertilization applied to such economic vegetable crop under the studied conditions.

\section{REFERENCES}

Abdel-Razzak, H. S., T. H. Solieman and T. H. Gamel. 2008. Influences of mineral nitrogen fertilizer sources and levels on vegetative growth, yield, curd quality and nutritional value of cauliflower (Brassica oleraceae var. botrytis, L.). Alex. J. Agric. Res. 53(2): 71-84.

Abou El-Magd, M. M., A. M. El-Bassiony and Z. F. Fawzy. 2006. Effect of organic manure with or without chemical fertilizers on growth, yield and quality of some varieties of broccoli plants. J. Appl. Sci. Res., 2(10): 791-798.

Ahmed, S. S.; S. A. El-Gendy; A. M. Hosni and R. M. Sabry. 2008. Growth and yield of artichoke (Romanian strain) as influenced by organic fertilization. Proc. $17^{\text {th }}$ Intern. Symp. of CIEC, 24-27 Nov. NRC (Micronutrient Project), Cairo-Egypt. pp, 59-69.

Association of Official Analytical Chemists (AOAC). 1995. Official methods of analysis, $15^{\text {th }}$ ed. AOAC International, Arlington, Virginia, USA (1995).

Badawy, A. S.; M. H. Hosseny; H. E. Mohamed and E. A. Fouad. 2007. Effect of organic and inorganic fertilization on growth, yield and quality of two garlic cultivars. Assiut J. Agric. Sci., 38(3): 29-44.

Bjelic, V. N. 1996. The influence of nitrogen quantities on cauliflower development and yield. Acta Hort., 462: 617621.

Chapman, H. D. and P. F. Pratt. 1978. Methods of Analysis for Soils, Plants and Waters. Division of Agric. Sci., Univ. California, Berkeley, USA. 309 p.

Cottenei, A.; M. Verloo; L. Kiekens; G. Velgh and R. Camerlynk. 1982. Chemical analysis of plants and soils. State Univ., Ghent Belgium. pp. 44-45.

Co-State Software. 2004. User's manual version. Cohort Tusson, Arizona, USA.

Csizinszky, A. A. 1996. Optimum planting time, plant spacing, and nitrogen and potassium rates to maximize yield of green cauliflower. Hort. Sci. 31(6): 930-933.

Duthie, G.G., Duthie, S.J., and Kyle, J. A. M. 2000. Plant polyphenols in cancer and heart disease: implications as nutritional antioxidants. Nutri. Res. Rev. 13: 79-106.

Elia, A.; P. Santamaria and F. Serio. 1998. Nitrogen nutrition, yield and quality of spinach. J. Sci. Food Agric. 76: 341346.

El-Leboudi, A. E.; E. M. Taha; M. S. Foda and Z. AbdelMoula. 1984. A study on the effect of organic manuring and inorganic nitrogen form on behavior of both tomato and squash plants. Ain Shams Univ. Ninth International Congress for Statistics, Computer Science, Social and Demographic Research. 31 March - 5 April. pp, 293-317.

El-Shafie, F. S. and E. E. El-Gamaily. 2002. Effect of organic manure, sulphur and microelements on growth, bulb yield, storability and chemical composition of onion plants. Minufiya J. Agric. Res. 27(2): 407-424.

Everaarts, A. P. and R. Booij. 2000. The effect of nitrogen application on nitrogen utilization by white cabbage (Brassica oleracea var. capitata) and on nitrogen in the soil at harvest. J. Hort. Sci. \& Biotechnol. 75(6): 705-712.

Farrag, A. M., J. F. Mishriky and A. M. El-Nagar. 2000. Effect of drip irrigation levels and nitrogen rates on growth and yield of cauliflower plants \& salts accumulation in soil. J. Agric. Sci. Mansoura Univ., 25(5): 2855-2875.

Greenwood, D. J. and J. Hunt. 1986. Effect of nitrogen fertilization on the nitrate content of field vegetables grown in Britain. J. Sci. Food Agric. 37: 373-383. 
Gutfinger, J. 1981. Polyphenols in olive oil. J. Am. Oil Chem. Soc. 58 (9): 966-968.

Hasanin, N. M. 2007. A comparison between the effect of compost and chicken manure fertilizers on productivity and fruit quality of two strawberry cultivars grown under transparent polyethylene low tunnels. Minufiya J. Agric. Res. 32(2): 419-440.

Helmy, A. M. and M. F. Ramadan. 2008. Physiological and chemical response of sunflower to some organic nitrogen sources and conventional nitrogen fertilizers under sandy soil conditions. Zagazig J. Agric. Res., 35(2): 315-341.

Isamu, B. 1972. Official methods of analysis of fertilizers. Publish National Institute of Agricultural Science, Ministry of Agriculture and Forestry, Nishigahara, Kila$\mathrm{Ku}$, Tokyo, Japan. 96 p.

Jones, J. B., Wolf, B. and Mills, H. A. 1991. Plant Analysis Handbook: A practical sampling, preparation, analysis and interpretation guide. Micro-Macro Publishing, Inc., Georgia, USA. 213p.

Kaoulnik, Y.; Y. Okon; J. Kigal; I. Nur and Y. Henis. 1981. Effects of temperature, nitrogen fertilization and plant age on nitrogen fixation by Setaria italics inoculated with Azospirillum brasilense (Strcin cd.). Plant Physiol. 68: 340-343.

Lisiewska, Z. and W. Kmiecik. 1996. Effects of level of nitrogen fertilizer, processing conditions and period of storage of frozen broccoli and cauliflower on vitamin C retention. Food Chem. 57(2): 267-270.

Markovic, V. and M. Djurovka. 1990. The effect of mineral nutrition on the yield and quality of cauliflower. Acta Hort. 267: 101-109.

Marschner, H. 1994. Mineral Nutrition in Higher Plants. Academic Press, Harcout Brace. Jovanovish Publisher, pp. 6-74.

Montemurro, F.; G. Debiase; D. Ferri; A. Fiore; C. Vitti and A. Vonella. 2008. Should N organic fertilizer strategies be expressed in relation to lettuce yield, $\mathrm{N}$ utilization and N status? Proc. 17 $7^{\text {th }}$ Intern. Symp. of CIEC, 24-27 Nov. NRC (Micronutrient Project), Cairo-Egypt. pp, 213-219.

Nonnecke, Ib. L. 1989. Vegetable Production. An avi Book. Van Nostrand Reinhold. New York. 657 p.

Pimpini, F., F. Venter and A. Wunsch. 1973. The influence of different nitrogen forms and increasing nitrogen doses on the content of total nitrogen and of nitrate in cauliflower plants. Acta Hort. 29: 307-317.

Ramarathnam, N., H. Ochi and M. Takeuchi. 1997. Antioxidative defense system in vegetables extracts. In: Shahidi, F., eds. Natural antioxidants. Chapter 5, 76-87. AOCS Press, Illinois, USA.

Rani, S. N. and K. Mallareddy. 2007. Effect of different organic manures and inorganic fertilizers on growth, yield and quality of carrot (Daucus carota L.). Karnataka J. Agric. Sci., 20(3): 686-688.

Rather, K.; M. Schenk; A. Everaarts and S. Vethman. 1999. Response of yield and quality of cauliflower varieties
(Brassica oleracea var. botrytis) to nitrogen supply. J. Hort. Sci. \& Biotechnol. 74(5): 658-664.

Romheld, V. and H. Marschner. 1991. Function of micronutrients in plants. In: J. J. Mortvedt; F. R. Cox; L. M. Shuman and R. M. Welch. 1991. Micronutrients in Agriculture. Second Edition. Soil Sci. Soc. Am., Inc. USA. Chapter 9, p. 304.

Russel, E. W. 1973. Soil Conditions and Plant Growth. $10^{\text {th }}$ Ed., The English Language Book Society and Longman. $849 \mathrm{p}$.

Schenk, M. K. 1998. Nitrogen use in vegetable crops in temperature climates. Hort. Rev., 22: 185-223.

Sharma, S. K., R. Sharma and B. N. Korla. 2002. Response of $\mathrm{N}$ and $\mathrm{P}$ on growth and yield of sprouting broccoli (Brassica oleracea var. italica). Indian J. Hort., 59(3): 313-315.

Silva, B. M.; P. B. Andrade; P. Valentao; F. Ferreres; R. M. Seabra and M. A. Ferrerea. 2004. Quince (Cydonia oblonga Miller) fruit (pulp, peel and seed) and jam. Antioxidant activity. J. Agric. Food Chem. 52: 47054712.

Smith, S. R. and P. Hadley. 1988. A comparison of the effects of organic and inorganic nitrogen fertilizers on the growth response of summer cabbage (Brassica oleracea var. capitata cv. Hispi F1). J. Hort. Sci., 63(4): 615-620.

Solieman, T. H. I.; A. G. Moussa; A. H. Abdel-Razik and E. M. El-Fadly. 2006. Effects of organic manures, mineral NPK and biofertilizer application on vegetative growth, yield and its components, and chemical composition of Brussels sprouts (Brassica oleraceae var. gemmifera). Alex. J. Agric. Res. 51(3): 85-103.

Sorensen, J. N., A. S. Johansen and K. Kaack. 1995. Marketable and nutritional quality of leeks as affected by water and nitrogen supply and plant age at harvest. J. Sci. Food Agric. 68: 367-373.

Sousa, C.; M. Taveira; P. Valentao; F. Fernandes; J. A. Pereira; L. Estevinho; A. Bento; F. Ferreres; R. M. Seabra and P. B. Andrade. 2008. Inflorescences of Brassicacea species as source of bioactive compounds: A comparative study. Food Chem. 110: 953-961.

Steel, R. G. D. and J. H. Torrie. 1980. Procedures of statistics ( $2^{\text {nd }}$ Edition), McGraw Hill Book Co., Inc. New York, USA.

Thompson, T. L., T. A. Doerge and R. E. Godin. 2000. Nitrogen and water interaction in subsurface Dripirrigated cauliflower: I. plant response. Soil Sci. Soc. Am. J. 64: 406-411.

Wang, Z-H. and S-X. Li. 2003. Effects of $\mathrm{N}$ forms and rates on vegetable growth and nitrate accumulation. Pedosphere 13: 309-316.

Wang, Z-H; S-X. Li and S. Malhi. 2008. Effects of fertilization and other agronomic measures on nutritional quality of crops. J. Sci. Food Agric., 88: 7-23.

Zahradnik, A. and K. Petrikova. 2007. Effect of alternative organic fertilizers on the nutritional value and yield of head cabbage. Hort. Sci. (Prague), 34(2): 65-71. 



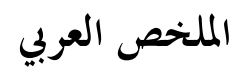

\section{كفاءة السماد النيتروجيني المعدلي والعضوي على جودة أقراص القنبيط}

\author{
هشام عبد الرزاق صالح، تامر حلمى جميل، عادل بدر النشرتي
}

و كذلك زيادة تركــيزات بعض العناصر الكبــــى والــصغرى مثل النيتروجين، الفوسفور، البوتاسيوم، الـــصوديوم، الزنـــك في أقراص القنبيط مقارنة بالمعاملات الأخرى. كما أظهرت النتــائج

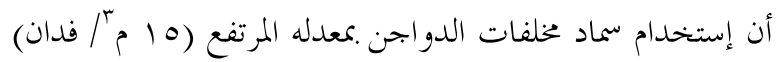
قد عكس تفوقا واضحا علي جميع صفات جودة الأقراص موضع الدراسة. قد عكس التأثير المشترك (تأثير التداخل) بــين الـسمادين النيتروجينى المعدلي والعضوى بمعدلاتم المختلفة نتائج إيبابية علي معظم صفات جودة أقراص القنبيط المدروسة. تشير نتائج تلك الدرسة أن إستخدام المستوى المتوسط مـــن

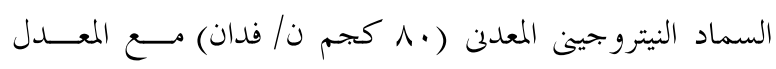

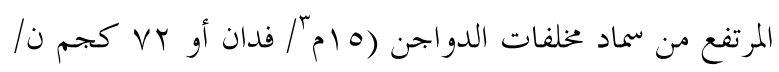

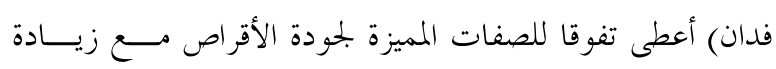
القيمة الغذائية للقرص.

يمكن التوصية من هذه الدراسة أنه بدلا من زيادة إســتخدام المعدلات المرتفعة من السماد النيتروجينى المعدلى في حقول إنتاج

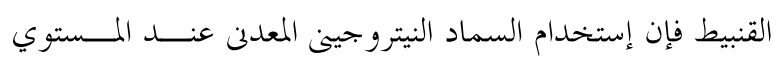

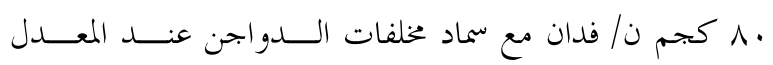

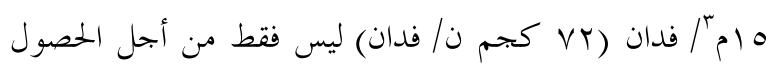

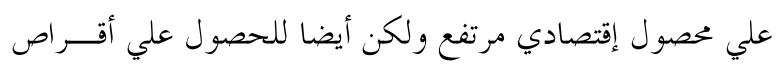

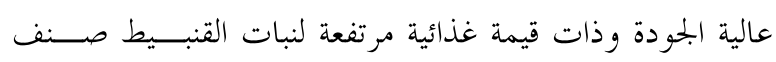
"أمشيرى" تحت ظروف منطقة الدراسة.
أجريت بتربتين حقليتين في محطة البحوث الزراعية التابعــة لكلية الزراعة جامعة الإسكندرية في الموسميين الــشتويين لعــامي

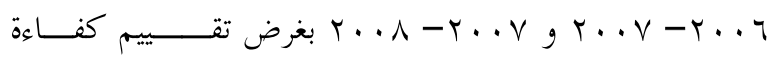
إستخدام مستويات مختلفة من السماد النيتروجينى المعدلي (•ع-

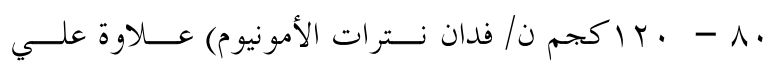
معاملة المقارنة (بدون إضافة سماد النيتروجين المعسـدني) وسمـــاد

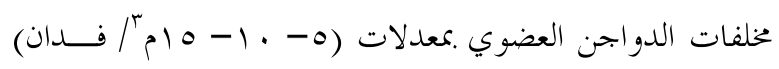
بالإضافة إلي معاملة المقارنة (عدم إضـــافة الــسماد العــضوي) وكذلك التأثير المشترك لمما على جودة أقر اص القنبيط صــنف "

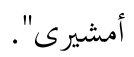

أظهرت النتائج تأثيرات إيجابية نتيجة لإضافة سماد النيتروجين

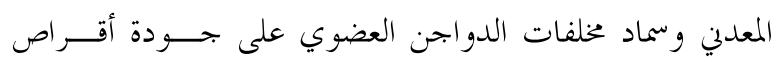

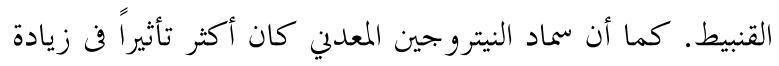
جودة الأقراص في حالة وجوده مع السماد العضوي مقارنة بحالة وجوده منفردا. أدي إضافة المستوى المرتفع من السماد النيتروجينى المعـــدني

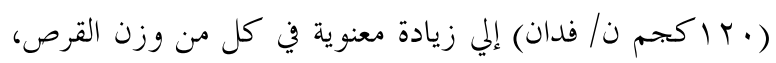
المركبات الفينولية، زيادة تركيز عناصر الكالسيوم و الماغنـسيوم

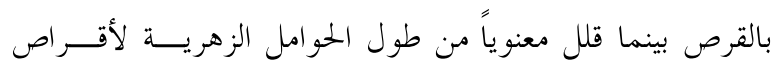

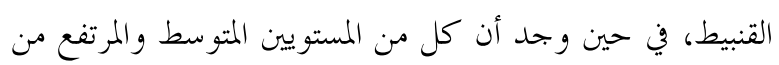

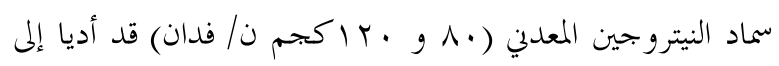
زيادة في صفات قطر القرص، محتوى الأقراص من المادة الجافة، النيتروجين البروتينى، البروتين الحقيقى، النيتروجين اللابروتيني 